\title{
The causal relationship between Carbon emissions and land urbanization quality: A panel data analysis for Chinese provinces
}

\author{
Hengzhou Xu, Wenjing Zhang
}

Abstract: The Chinese government, like many others around the world, has set carbon targets that by the time of 2020 , to achieve a $40-45 \%$ decrease in $\mathrm{CO}_{2}$ emissions per GDP compared with that of 2005. In some parts of China, short-term economic needs have dominated urban planning, while in other areas - especially in recent years-emphasis has shifted to the quality of urban development. This paper contributes to the literature as placing emphasis on the quality of land use as well as detecting possible causal links between land urbanization quality(LUQ) and carbon emissions using panel data from at provincial level from 2004 to 2013. The results show that: There is bidirectional long-run causal relation between carbon emission and LUQ on the national scale, which implies that the two are jointly determined and that they simultaneously affect each other. As the case of recovery to the equilibrium, Eastern regions have the fastest speed, followed by the Central and the Western ranked at last. Further, what worth noting is LUQ contribute to reducing carbon emissions, indicating the ongoing industrial restructuring and green developments have come into force. Moreover, we deduce that the Central region has the highest potential for energy conservation. We further propose that emphasis should be placed on promoting the degree of LUQ and energy conservation in the implementation during the New-type Urbanization Plan (2014-2020).

Keywords: Land Urbanization Quality, Carbon Emission, Panel Data, China

\section{Introduction}

As a result of extensively increase in Greenhouse gas emissions (GHGs), climate change, especially global warming serves as one of the most challenging issues in this era. Reducing GHGs has become a common goal around the world, China's actions to control greenhouse gas emissions goal: By 2020, to achieve a $40-45 \%$ decrease in $\mathrm{CO}_{2}$ emissions per GDP compared with that of 2005. By 2020, to achieve non-fossil energy accounts for the proportion of primary energy consumption to $15 \%$; to increase 40 million hectares of forest area through reforestation and strengthening forest management. Faced with the new situation of market economy, energy consumption, globalization and human contradiction, the National Land Use Plan (2006-2020), proposed combining land-use with environment, demographic, ecological determinants(Xu et al., 2015).There are extensive research on energy-growth-environment nexus (Farhani \& Ozturk, 2015; Dogan \& Seker,2016), real-life case studies on sustainability (Zhao et al., 2006; Chau \& $\mathrm{Wu}, 2010$; Wang et al., 2014), and social-economic-ecology issues related to China's urbanization (Chen et al., 2010; He et al., 2016).

Land Urbanization refers to the rising process of the proportion that land with urban 
morphological characteristics in total land area in a region or country (Lu et al., 2007). Land urbanization closely related to new-type urbanization strategy, transformation of economic development, farmland protection, social stability, sustainable development, research concerning land urbanization has become the focus in the area. The connotation of land urbanization mainly interpreted in two ways in former studies. The first mainly focus on change of land ownership, nationalization of land serve as the main character. The other focus on the process of land pattern changes, which mainly refers to the rural-urban land use change (Hu et al.,2014). Land use concepts have to integrate multiple goals such as profit for farmers, biodiversity, resource protection, lifestyle and aesthetics (Fohrer, Haverkamp, \& Frede, 2005; Reed et al., 2016). There are some differences between land urbanization quality and existing theory, for instance, sustainable land use and smart land use. Sustainable land use gives emphasize to meet the needs of contemporary people and future generations (Fröhlich et al., 2013). Meanwhile, the latter mainly refers to the practice of smart growth theory (SGT) in urban land use (Edwards \& Haines, 2007). The intention of Land urbanization quality(LUQ) in this paper put emphasis on the efficiency improvement of urban land use, take into consideration the moderation development of land urbanization with economic, social and ecological development.

This empirical study makes several contributions to the existing energy-development-environment literature. Since the study, for the first time in the literature, to investigate the relationships between LUQ and $\mathrm{CO}_{2}$ emissions in China. Moreover, land serves as the carrier of urban development, concerns about land use and its relevant factors have long been heated issues especially in developing countries (Lin et al., 2015). Which mainly refers to health (Wang et al., 2016), land cover change (Fu \& Weng, 2016; De Rosa, Knudsen, \& Hermansen, 2016), arable land (Brown \& Matsuo-Chun, 2016; Liu et al., 2016) and regional planning (Davidson\& Wibberley, 2016; Wei et al., 2016). Since China is a vast country with significant regional differences, thus, the relationship between China's LUQ and $\mathrm{CO}_{2}$ emissions must be investigated from the national to the regional level. To enrich the existing research on related areas, the present study trying to investigate the causal relationship between LUQ and carbon emissions at the provincial level in China.

Further, this study makes further progress as emphasizing the importance of quality of land urbanization in the country. Since improving the efficient land use is commonly recognized as of vital significance in balancing the farmland protection and the accommodation of socio-economic development, especially for a country like China with sharp conflict between supply and demand of land, as well as land-human relationship and rapid urbanization progress(Du, Thill \& Peiser, 2016).To enrich the literature in the related area, the purpose of this study are as follows: To begin with, we tend to establish an evaluation system for LUQ which emphasis the sustainable development of urban land use in China; Further, for the first time in the literature, this study tend to investigate the relationships between LUQ and $\mathrm{CO}_{2}$ emissions in China and take into consideration of regional difference. The study trying to present reference value for urban development, energy conservation and emission reduction.

\section{Methods}

\subsection{Carbon emission from energy consumption}


As for carbon emissions, since China's statistics agency did not disclose $\mathrm{CO}_{2}$ emissions data, former studies mostly estimated by multiplying the total energy consumption of its carbon emission factors. Given the fact that $95.3 \%$ of current global $\mathrm{CO}_{2}$ emissions due to from fossil fuels, while the effect of hydropower, nuclear power and other new energy emissions is negligible (Olivier, Janssens-Maenhout \& Peters, 2012). Besides, the case in China have long been performed with regard to carbon emissions from energy consumption (Zhao et al., 2014), since this accounts for about $90 \%$ of China's total carbon emissions (Chuai et al., 2015). Based on above facts, energy-related $\mathrm{CO}_{2}$ emissions in thus study were calculated using the unified standard method recommended by the guidelines of the Intergovernmental Panel on Climate Change (IPCC) (IPCC, 2007; Intergovernmental Panel on Climate Change, 2015). The formula is given by

$$
C E=\sum_{i=1}^{6} S_{i} * F_{i} * E_{i}
$$

where $C E$ represents the factor of carbon emission, $S_{i}$ represents the factor of standard coal coefficient for every energy type $i, E_{i}$ is the consumed amount of energy type $i, F_{i}$ is the carbon emission coefficient of energy type $i$, and $i$ represents the energy types, which mainly refers to coal, coke, crude oil, gasoline, diesel and kerosene (Chuai et al., 2015). Carbon emission coefficients are taken from the average number from the National Energy Research Institute, the US Energy Information Administration and the Japan's Institute of Energy Economics published, and standard coal coefficients are from the National Energy Research Institute.

Table 1 Standard coal coefficients and Carbon emission coefficients of major energy types

\begin{tabular}{lll}
\hline Energy & Carbon emission coefficient $(\mathrm{t} / \mathrm{t})$ & Standard coal coefficient $(\mathrm{kg} / \mathrm{kg})$ \\
\hline Coal & 0.711 & 0.714 \\
Coke & 0.855 & 0.971 \\
Crude oil & 0.586 & 1.429 \\
Gasoline & 0.554 & 1.471 \\
Diesel & 0.592 & 1.457 \\
Kerosene & 0.571 & 1.471 \\
Fuel oil & 0.619 & 1.529 \\
Natural gas & 0.418 & 1.33 \\
\hline
\end{tabular}

\subsection{Evaluation system of LUQ}

Land urbanization includes not only the process of land from rural to urban transformations in the type, but the total urban land (including land newly turned into urban land), the process that continuously to improve the effectiveness of land use. In this study, we consider the quality of land urbanization at the level of improvement in efficiency of urban land use during the aforementioned process. Based on this understanding, the present study trying to establish land urbanization determinants model for market economies in general and China from both supply and demand of land urbanization (fig 1).

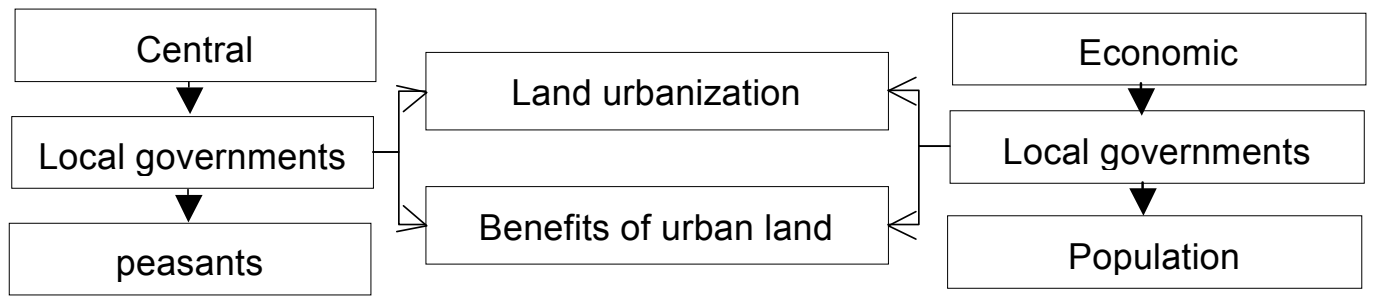


Figure 1 Theoretic model for determinants of land urbanization quality in China

In the general market economies, where land supply is mainly affected by the effects of rural land owners, land urbanization is mainly affected by the economic and population needs of, the government plays the role of demand regulation in the process. As the case in China, however, land supply mainly affected by local governments, demand of land urbanization is mainly affected by the economic urbanization, population urbanization and local governments, thus the determinants of land urbanization quality mainly including economic urbanization, population urbanization and local Governments behavior.

Former studies are extensively concerned with index system of urbanization including environmental concerns, social-economic influence, overall urban-rural development and other determinants since 2001 (Zhou et al., 2015; Xu et al., 2016). The common indicator represents land urbanization in former studies is the proportion of a built-up area to the total area. There is extensive research on evaluation index system on land use, for instance, "input-output" (IO), "Ecological-Social-Economic"(ESE), "high efficient and intensified"(IEH), "pressure-state-response"(PSR), as well as numerous index system constructed in accordance with various aspects of urban land use (Hubacek \& Giljum., 2003; Feng et al., 2007). On the basis of a summary of available research, for the first time in the literature, this study establishes an evaluation system from four perspectives, moderation and economic-social-ecological benefits of land urbanization. This study finally established evaluation system for LUQ as shown in Table 2 in by screening means of statistical method, and considering the availability and representativeness of the data.

Table 2 Evaluation system of LUQ

\begin{tabular}{|c|c|c|c|c|}
\hline $\begin{array}{l}\text { Layer of } \\
\text { target }\end{array}$ & Layer of factors & Layer of index & Weight & Unit \\
\hline \multirow[t]{11}{*}{ LUQ } & \multirow{4}{*}{$\begin{array}{l}\text { Moderation of land } \\
\text { urbanization }\end{array}$} & Urban economic expansion coefficient & 0.1519 & $\%$ \\
\hline & & Urban population expansion coefficient & 0.1249 & $\%$ \\
\hline & & $\begin{array}{l}\text { Secondary and tertiary industry output value } \\
\text { per unit area }\end{array}$ & 0.0709 & $\begin{array}{l}\mathrm{RMB} \\
10,000 / \mathrm{km}^{2}\end{array}$ \\
\hline & & Fixed-asset investment per unit area & 0.0805 & $\$ 10000 / \mathrm{km}^{2}$ \\
\hline & \multirow[t]{4}{*}{$\begin{array}{l}\text { Economic benefits of urban } \\
\text { land utilization }\end{array}$} & $\begin{array}{l}\text { Budgetary revenue of local governments per } \\
\text { unit area }\end{array}$ & 0.0675 & $\begin{array}{l}\text { RMB } \\
10,000 / \mathrm{km}^{2}\end{array}$ \\
\hline & & Total industrial output value per unit area & 0.0800 & $\begin{array}{l}\text { RMB } \\
10,000 / \mathrm{km}^{2}\end{array}$ \\
\hline & & Population density & 0.0378 & People $/ \mathrm{km}^{2}$ \\
\hline & & Residential land per capita & 0.0653 & $\mathrm{~m}^{2} /$ people \\
\hline & \multirow{3}{*}{$\begin{array}{l}\text { Social benefits of urban land } \\
\text { utilization }\end{array}$} & Transportation land ratio & 0.0673 & $\%$ \\
\hline & & Public facilities ratio & 0.0539 & $\%$ \\
\hline & & $\begin{array}{l}\text { Secondary and tertiary industry employer per } \\
\text { unit area }\end{array}$ & 0.0159 & People $/ \mathrm{km}^{2}$ \\
\hline
\end{tabular}




\begin{tabular}{|c|c|c|c|}
\hline \multirow{5}{*}{$\begin{array}{l}\text { Ecological benefits of urban } \\
\text { land utilization }\end{array}$} & Green covered area as $\%$ of completed area & 0.0286 & $\%$ \\
\hline & Waste water emissions per unit area & 0.0419 & Ton $/ \mathrm{km}^{2}$ \\
\hline & Industrial waste gas per unit area & 0.0468 & Ton $/ \mathrm{km}^{2}$ \\
\hline & Collection of consumption waste per unit area & 0.0337 & Ton $/ \mathrm{km}^{2}$ \\
\hline & $\begin{array}{l}\text { Environmental protection investment } \\
\text { per unit area }\end{array}$ & 0.0330 & $\begin{array}{l}\text { RMB } \\
10,000 / \mathrm{km}^{2}\end{array}$ \\
\hline
\end{tabular}

\subsection{Data source and data processing}

Data used in this paper comes mainly from the China Energy Statistical Yearbook (2005-2014), which including every calculated source of energy at provincial level. The data for indicators in the evaluation system of LUQ are mainly from China Statistical Yearbook (2005-2014), while considering the integrity of the data, the analysis did not include Tibet. To ensure comparability of the statistics, all indicators related to gross domestic product was converted to the constant price index in 2000.

This study employs subjective weighting Delphi methods to calculate the weight of subjective evaluation $\left(\mathrm{w}_{1}\right)$; and then using entropy method to calculate objective weight of evaluation indexes $\left(\mathrm{w}_{2}\right)$. We assume that $\mathrm{W}$ is the weight of empowerment after the two methods obtained by a linear combination, namely:

$$
W=\theta_{1} w_{1}+\left(1-\theta_{1}\right) w_{2},(1)
$$

where $\theta_{1}$ and $1-\theta_{1}$ represent the proportion of $w_{1}$ and $w_{2}$, respectively.

Based on minimizing the sum of the squares of the deviation of two methods, we build the following objective function (Han \& Wei,2015):

$$
\min z=\left[\sum_{j=1}^{n}\left(W-w_{1}\right)^{2}+\left(W-w_{2}\right)^{2}\right]
$$

Combined with (1) we got

$$
\min z=\left[\sum_{j=1}^{n}\left(\theta_{1} w_{1}+\left(1-\theta_{1}\right) w_{2}-w_{1}\right)^{2}+\left(\theta_{1} w_{1}+\left(1-\theta_{1}\right) w_{2}-w_{2}\right)^{2}\right]
$$

Make the derivative of (3) zero and the equation is given as

$$
W=0.5 w_{1}+0.5 w_{2}
$$

Finally, this study adopts weighted comprehensive assessment for the final evaluation results of LUQ, which is expressed as

$$
L U Q_{i}=\sum_{i=1}^{n} C_{j} W_{j}
$$

where $L U Q_{i}$ represents the LUQ of each province, $C_{j}$ represents standardized value of 
each indicator for every province $\mathrm{i}, W_{j}$ represents the weight of each index, and $\mathrm{n}$ is the number of indicators in the evaluation system of LUQ.

Since China has a vast area with various level of economic growth, endowments as well as geographic difference, therefore, in this study, according to the standards from National Bureau of Statistics of China, the studied area is divided into Eastern, Central and Western region (Meng et al, 2012; Wang, 2013; Mu et al., 2016). Where the eastern provinces, including Beijing, Fujian, Guangdong, Guangxi, Hainan, Hebei, Jiangsu, Liaoning, Shandong, Shanghai, Tianjin and Zhejiang. The Central area refers to Anhui, Henan, Heilongjiang, Hubei, Hunan, Inner Mongolia, Jiangxi, Jilin and Shanxi. And Western provinces including Gansu, Guizhou, Sichuan, Ningxia, Qinghai, Shaanxi, Xinjiang and Yunnan. All the calculations in this study are completed using EViews 8.0.

\section{Empirical results}

\subsection{Unit root test of panel data}

The first step in the investigation of causality is to determine whether the series has any integration orders, similar to processing of time series data, the panel Granger causality, starts form unit root test to determine the stability, and then Co-integration test for possible relation, finally the Granger-type model for causal relations (Tugcu, 2014). The logarithm of LUQ $\ln ($ LUQ) and carbon emissions $\ln (\mathrm{CE})$ are employed for the analysis. Table 3 reported the descriptive statistics for the statistics in the study. The evaluation results of LUQ at the provincial level are shown in table 4. Given that heterogeneity can arise from different land use levels and economic conditions in each province, this study adopts the Im-Pesaran-Shin (IPS) test, which emphasizes parameter heterogeneity in dynamic panel models to avoid biases that may arise from including it in the model. Further, IPS test has less strict requirements compared to other methods on homogeneity, which more in line with the characteristics of the economic data, recognizing both the scale of the whole series and part of unstable individuals (Rizvi \& Nishat, 2009). The test is generally based on the following equation:

$$
\Delta y_{i t}=\beta_{i} y_{i, t-1}+\alpha_{i}+u_{i t} \quad(\mathrm{i}=1,2, \ldots, \mathrm{N} ; \mathrm{t}=1,2, \ldots, \mathrm{T})
$$

where $\beta_{\mathrm{i}}$ denotes the coefficients, $u_{i t}$ signifies the estimated panel residuals, and $\alpha_{i}$ represents the cross-section fixed effect. The alternative and null hypothesis can be written as follows:

$$
\begin{array}{ll}
H_{o}: \beta_{i}=0 & i=1,2, \ldots N_{1} \\
H_{i}: \exists i, \beta_{i}<0 & i=N_{1}+1, N_{1}+2, \ldots N
\end{array}
$$

A unit root exists under the null hypothesis, while no unit root exists under the alternative hypothesis.

Table 3 Descriptive statistics of these two series for all the three regions

\begin{tabular}{lllll}
\hline Region & Variable & Mean & Std.dev & Obs \\
\hline \multirow{2}{*}{ National scale } & $\ln ($ LUQ $)$ & 3.7403 & 0.2138 & 300 \\
Eastern China & $\ln (\mathrm{CE})$ & 8.7942 & 0.8101 & 300 \\
& $\ln (\mathrm{LUQ})$ & 3.8100 & 0.2129 & 110
\end{tabular}




\begin{tabular}{|c|c|c|c|c|c|}
\hline \multirow{3}{*}{ Central China } & & $\ln (\mathrm{CE})$ & 8.9699 & 0.9671 & 110 \\
\hline & & $\ln (\mathrm{LUQ})$ & 3.6894 & 0.1883 & 80 \\
\hline & & $\ln (\mathrm{CE})$ & 9.0149 & 0.4816 & 80 \\
\hline \multirow{2}{*}{ Western China } & & $\ln (\mathrm{LUQ})$ & 3.6582 & 0.2814 & 110 \\
\hline & & $\ln (\mathrm{CE})$ & 8.4987 & 0.7253 & 110 \\
\hline \multicolumn{6}{|c|}{ Table 4 Results of the IPS unit root tests for the sample } \\
\hline Region & Variable & without trend & Prob. & with trend & Prob. \\
\hline \multirow{4}{*}{ Eastern China } & $\ln (\mathrm{LUQ})$ & -2.108 & 0.018 & -0.468 & 0.320 \\
\hline & $\ln (\mathrm{CE})$ & -3.311 & 0.001 & -1.785 & 0.118 \\
\hline & d(LUQ) & -3.227 & 0.001 & -3.396 & 0.000 \\
\hline & $\mathrm{d}(\mathrm{CE})$ & -4.015 & 0.000 & -1.433 & 0.076 \\
\hline \multirow{4}{*}{ Central China } & $\ln (\mathrm{LUQ})$ & -2.806 & 0.003 & -0.784 & 0.217 \\
\hline & $\ln (\mathrm{CE})$ & -1.340 & 0.090 & -1.572 & 0.058 \\
\hline & $\mathrm{d}(\mathrm{LUQ})$ & -2.153 & 0.016 & -3.338 & 0.000 \\
\hline & $\mathrm{d}(\mathrm{CE})$ & -2.925 & 0.002 & -2.993 & 0.000 \\
\hline \multirow{4}{*}{ Western China } & $\ln (\mathrm{LUQ})$ & -3.449 & 0.000 & -0.920 & 0.179 \\
\hline & $\ln (\mathrm{CE})$ & 0.601 & 0.726 & -1.289 & 0.099 \\
\hline & d(LUQ) & -4.436 & 0.000 & -3.290 & 0.000 \\
\hline & $\mathrm{d}(\mathrm{CE})$ & -5.066 & 0.000 & -3.568 & 0.000 \\
\hline
\end{tabular}

Table 4 illustrates the empirical results of IPS panel unit root tests for all the sub-panel in the study. As shown in the table that all variables are constant after first-difference, while the results on the level varied (Kumar Mandal \& Madheswaran, 2010). However, when the first difference is applied, they are stationary. In other words, the relationship between LUQ and carbon emission can be identified by the co-integration test.

\subsection{Panel co-integration analysis}

Having established that LUQ and carbon emission all stable after first-level is employed, the present study further tests whether or not a long-run relationship exists between them. Three panel co-integration tests are commonly used in the panel co-integration analysis: the Johansen-Fisher (1988), Kao (1999), and Pedroni (1999, 2004) tests (Khan et al., 2015). Combined with former studies, the Pedroni test is adopted to estimate the long-run relationship between LUQ and carbon emission because it allows for heterogeneous variance across individual numbers of the panel (Farhani et al., 2014). The Pedroni test is based on the general panel fixed effects model:

$$
y_{i t}=\alpha_{i}+\delta_{i} t+X_{i t} \beta_{i}+u_{i t}, \quad(\mathrm{i}=1,2, \ldots, \mathrm{N} ; \mathrm{t}=1,2, \ldots, \mathrm{T})
$$

where $y_{i t}$ and $X_{i t}$ are integrated of order one in levels, $\beta_{\mathrm{i}}$ denotes the coefficients, uit signifies the estimated panel residuals, and $\alpha i$ and $\delta i$ are the cross-section fixed effect and period fixed effect, respectively.

The auto-regressive test for the estimated panel residuals is as follows:

$$
\hat{e}_{i t}=\rho_{i} u_{i, t-1}+v_{i t}
$$

where $\mathrm{v}_{\text {it }}$ denotes the random error term and $\rho_{i}$ is the autoregressive term of the estimated 
residuals. Pedroni's framework provides co-integration tests based on seven residual-based statistics (Pedroni, 1999). Among these seven statistics, the panel v-statistic, panel r-statistic, panel PP(Phillips-Perron,1988) statistic, and panel ADF (Augmented Dickey-Fuller) t-statistic are based on pooling the residuals of the regression along the within-dimension of the panel. The other three (i.e., Group rho-Statistic, Group PP-Statistic, and Group ADF-Statistic) are based on pooling the residuals of the regression along the between-dimension of the panel (Al-Mulali \& $\mathrm{Sab}, 2012)$. All the seven tests indicate the absence of co-integration:

$$
\begin{aligned}
& H_{o}: \rho_{i}=1 \mathbf{£} \rightsquigarrow H_{1}: \rho_{i}=\rho<1 \\
& H_{o}: \rho_{i}=1 \text { £»H} H_{1}: \rho_{i}<1
\end{aligned}
$$

A co-integration relationship exists under the null hypothesis, but no co-integration relationship exists under the alternative hypothesis.

According to Örsal (2007), the panel ADF-statistic performs better than the three other within-dimension-based statistics and the three other between-dimension-based statistics ( $Q u$ et al., 2013). Therefore, this study primarily makes the conclusion on panel ADF statistics (shown in Table 5) that the nullity of non-co-integration of the variables is rejected at the $1 \%$ significance level.

Table 5 Pedroni panel co-integration tests

\begin{tabular}{llllllll}
\hline & \multicolumn{2}{l}{ Eastern China } & \multicolumn{2}{l}{ Central China } & \multicolumn{2}{l}{ Western China } \\
\hline & Statistic & Prob. & Statistic & Prob. & Statistic & Prob. \\
& -1.0233 & 0.7240 & -0.2538 & 0.6834 & 1.0510 & 0.4736 \\
Panel v-Statistic & 0.7601 & 0.7263 & 0.0973 & 0.4843 & -1.1938 & 0.1650 \\
Panel rho-Statistic & -1.8627 & 0.0061 & -3.6808 & 0.0000 & -3.6379 & 0.0000 \\
Panel PP-Statistic & -3.2312 & 0.0009 & -3.7119 & 0.0001 & -3.5069 & 0.0000 \\
Panel ADF-Statistic & 1.8037 & 0.9644 & 1.4395 & 0.9250 & 0.9360 & 0.8254 \\
Group rho-Statistic & -3.5072 & 0.0002 & -3.0064 & 0.0013 & -4.2116 & 0.0000 \\
Group PP-Statistic & -3.5552 & 0.0002 & -4.1802 & 0.0000 & -3.9960 & 0.0000 \\
Group ADF-Statistic & & & & & & \\
\hline
\end{tabular}

\subsection{Panel causality test between LUQ and carbon emissions}

Granger test based on the use of $\mathrm{F}$ - statistics to verify lag value if $\mathrm{X}$ significantly affect $\mathrm{Y}$, and has taken into account the lag value of $Y$; if the effect is not significant, then called $X$ does not Granger cause $\mathrm{Y}$, and if the effect is significant, then concluded as $\mathrm{X}$ does Ganger cause $\mathrm{Y}$. Similarly, this method can also be used to test if $\mathrm{Y}$ is the Ganger reason of X. As Granger theorem states: If there is a co-integration relationship between two variables, then we can use the error correction model to represent their relationship.

In the empirical study, if the variable is non-stationary, then the application F-statistic estimating coefficient may can cause problems. Therefore, empirical studies generally making the difference and other conversion sequence to pass unit root test. Granger is further proof, co-integration relationship between the variables in first-difference, there must be at least one direction of causality, whether unidirectional or bidirectional between variables (Granger, 1969). 
Therefore, in this study, we have adopted Granger causality model in the form of vector error correction model(VECM) to investigate possible causal relations between carbon emissions and LUQ with direct description of short-term fluctuations and long-term equilibrium between the variables. The Granger causality model with a causality error correction is expressed as follows:

$$
\begin{aligned}
& \Delta \ln C E_{i t}=\theta_{1 t}+\beta_{1 t} \Delta \ln L U Q_{i t}+E C M_{i} \gamma_{i, t-1}+u_{1 i t} \\
& E C M_{t-1}=\ln C E_{t-1}-\vartheta_{0}-\beta_{1 t} \ln L U Q_{t-1} \\
& \Delta \ln L U Q_{i t}=\theta_{2 t}+\beta_{2 t} \Delta \ln C E_{i t}+E C M_{i} \gamma_{i, t-1}+u_{i t} \\
& E C M_{t-1}=\ln L U Q_{t-1}-\vartheta_{1}-\beta_{1 t} \ln C E_{t-1}
\end{aligned}
$$

Where $\Delta$ denotes the first differences and 1 is the optimal lag length determined by Akaike's information criterion. Using the specification in Eqs. (9) and (10) allows us to test for both short- and long-run causality. Specifically, in the short run, smart land use does not Granger-cause urban scale if and only if $\beta_{1 \mathrm{t}}$ is equal to 0 in Eq. (9). In the reverse case, urban scale does not Granger-cause smart land use if and only if $\beta_{2 t}$ is equal to 0 in Eq. (10). Long-run causality can be established by examining the significance using a t-test on the coefficient of the error correction term $\gamma_{i, t-1}$ in Eqs. (9) and (10). Meanwhile, the coefficient of error correction term should have a negative sign and is significantly different from 0 . The negative sign means that the deviation event between the actual and long-run equilibrium level is adjusted back to the long-run

\begin{tabular}{|c|c|c|c|c|}
\hline \multirow[t]{2}{*}{ Region } & \multirow[b]{2}{*}{ Null hypotheses } & \multicolumn{2}{|l|}{$\begin{array}{l}\text { Short-run } \\
\text { coefficient }\end{array}$} & \multirow{2}{*}{$\begin{array}{l}\text { Long-run } \\
\text { t-Statistic } \\
\text { ECM(-1) }\end{array}$} \\
\hline & & $\mathrm{D}(\mathrm{CE})$ & $\mathrm{D}(\mathrm{LNQ})$ & \\
\hline \multirow{2}{*}{ National scale } & \multicolumn{2}{|l|}{$\ln (\mathrm{LNQ})$ does not cause $\ln (\mathrm{CE})$} & $-0.0687 * * *$ & $-0.0272 * * *$ \\
\hline & \multicolumn{2}{|c|}{$\ln (\mathrm{CE})$ does not cause $\ln (\mathrm{LNQ})-0.2981 * *$} & & $-0.4143 * * *$ \\
\hline \multirow{2}{*}{ Eastern China } & \multicolumn{2}{|l|}{$\ln (\mathrm{LNQ})$ does not cause $\ln (\mathrm{CE})$} & -0.0159 & $-0.0225 * *$ \\
\hline & \multicolumn{2}{|c|}{$\ln (\mathrm{CE})$ does not cause $\ln (\mathrm{LNQ})-0.0585$} & & $-0.4624 * * *$ \\
\hline \multirow{2}{*}{ Central China } & \multicolumn{2}{|l|}{$\ln (\mathrm{LNQ})$ does not cause $\ln (\mathrm{CE})$} & $-0.1134 * * *$ & $-0.0400 * * *$ \\
\hline & \multicolumn{2}{|c|}{$\ln (\mathrm{CE})$ does not cause $\ln (\mathrm{LNQ})-0.7513^{* *}$} & & $-0.4007 * * *$ \\
\hline Western & \multicolumn{2}{|l|}{$\ln (\mathrm{LNQ})$ does not cause $\ln (\mathrm{CE})$} & $0.0729 * * *$ & $-0.0683 * * *$ \\
\hline China & \multicolumn{2}{|c|}{$\ln (\mathrm{CE})$ does not cause $\ln (\mathrm{LNQ}) 0.1189$} & & $-0.3243 * * *$ \\
\hline
\end{tabular}
relationship in the current periods to clear this discrepancy. Finally, a joint test is conducted on $\gamma$ $i, t-1$ and the respective interactive terms to check for strong causality.

Table 6 Panel causality test results

Notes: The lag lengths are selected using Akaike's information criterion. *, **, and *** denote significance at $10 \%, 5 \%, 1 \%$ level, respectively.

Panel Granger causality results are reported in Table 6. The statistical significance of the coefficients associated with the error correction term provides evidence of an error correction mechanism that drives the variables back to their long-run relationship (Farhani et al., 2014). According to the coefficient of the error correction term, there is a bidirectional long-run relationship between LUQ and carbon emission across the country, where all the coefficients are 
statistically significant. When short-term fluctuations deviate from the long-term equilibrium, error correction term will apply adjusting strength of -0.0272 adjustment back to equilibrium, with the strength of -0.4143 on the reverse (Li \& Zhang, 2014).

As for the Eastern China, only long-term bidirectional causal relation is found between the two series. The possible explanation lies in the development level of Eastern provinces have already entered the age of mass consumption according to Rostow's stages of economic growth (Rostow, 1959). Namely, during this stage, the provinces in Eastern China have relatively low construction rate with higher land use efficiency, thus the level of LUQ remains in stationary phrase. When short-term fluctuations deviate from the long-term equilibrium, error correction term will apply adjusting strength of -0.0225 adjustment back to equilibrium, with the strength of -0.4624 on the reverse.

In terms of Central China, there are both bidirectional short-run and long-run causal relation between LUQ and carbon emissions. Probable reason lies in that manufacturing and every consumption increased sharply over the years, which contribute a lot to the carbon emission. Similar findings as Yao, Wang, \& Zhang. (2016) state that increasing human demands has led to increasing impacts on environment and ecosystem while reduction in energy consumption and carbon emission can contribute to the situation. Further, when short-term fluctuations deviate from the long-term equilibrium, error correction term will apply adjusting strength of -0.0400 adjustment back to equilibrium, with the strength of -0.4007 on the reverse.

As the case in Western China, there is only uni-directional causal relation running from LUQ to carbon emissions in the area. Possible reasons lie in the development level of most western provinces still in the stage of take-off according to Rostow's stages of economic growth (Rostow, 1959). In other words, cities in the western area count on fast urbanization to promote economic development. Faced with sensitive ecological environment in the area, development of the western provinces is in urgent need of establishing sustainable mode (Jin \& Wang, 2016). When short-term fluctuations deviate from the long-term equilibrium, error correction term will apply adjusting strength of -0.0683 adjustment back to equilibrium, with the strength of -0.3243 on the reverse.

\subsection{Fully modified ordinary least square (FMOLS) panel estimates}

After understanding of causal relations, then how about level and direction of the force between the variables? While direct application of ordinary least squares (OLS) here might lead to biased results .In order to further clarify the effects of the degree and direction between variables, we employed FMOLS(Fully modified OLS) approach proposed by Hansen\&Phillips.(1990) to investigate the specific level of effects between carbon emissions and LUQ (Asumadu-Sarkodie \& Owusu, 2016). The core idea of the FMOLS method is employing nonparametric amended to eliminate the influence of noise parameters on the asymptotic distribution of statistics in the results of OLS estimator(Destek, Balli\& Manga,2016; Ogundari, 2016).Further, FMOLS is especially suitable for the estimation of small samples, as the case in this study(Sbaouelgi\& Boulila, 2016). The estimation results of FMOLS are reported in Table 7.

Table 7 FMOLS results between carbon emissions and LUQ

\begin{tabular}{lllllll}
\hline Region & $\ln (\mathrm{LUQ})$ & $\mathrm{t}$-value & Prob. & $\ln (\mathrm{CE})$ & $\mathrm{t}$-value & Prob. \\
\hline National scale & -0.5372 & -4.1167 & 0.0001 & -0.0983 & -2.1580 & 0.0319 \\
Eastern China & -0.4415 & -3.3513 & 0.0012 & -0.1698 & -4.4251 & 0.0000
\end{tabular}




\begin{tabular}{lllllll} 
Central China & -0.6253 & -2.9262 & 0.0048 & -0.2668 & -8.9843 & 0.0000 \\
Western China & -0.3270 & -2.5200 & 0.0134 & -0.1724 & -9.4583 & 0.0000 \\
\hline
\end{tabular}

Considering both FMOLS regression results and the Granger test results, the improvement of LUQ has negative impacts on carbon emissions, and due to bidirectional causal relation between the two series, the increase of carbon emissions contribute negatively to the improvement of LUQ, thus this studies suggest that improving the quality of urban land is currently feasible path for energy saving and emission reduction especially suitable for the condition in China.Indicate the ongoing industrial restructuring and green developments have come into force.

Nevertheless, the negative effects between variables have certain regional differences, as the case of Central China, has bidirectional largest effects between LUQ and carbon emissions(-0.6253 and -0.2668), while combined with the fast urban development in the area,we deduce that the area has the highest potential for emission reduction. In respect of Eastern China, the effects of carbon emissions is superior to that of LUQ. Moreover, the situation of the Western China is similar to that of Eastern China.

\section{Conclusion and policy recommendations}

The study analyzes the causal relationship between LUQ and carbon emissions considering regional difference in China during 2004-2013 using panel data models. The results show that there is bidirectional long-run relationship between LUQ and carbon emission across the country, where Eastern China only has no short-run causal relation. Central China has bidirectional short-run relation and Western China has uni-directional short-run causal relation. As the case of recovery to the equilibrium, Eastern regions have the fastest speed, followed by the Central and the Western ranked at last. The regression results further indicate that LUQ contribute positively on emission reduction while the effects ranked the same as the recovery period. Based on the empirical results, this study further suggests following policy implications.

To begin with, there are two kinds of means to reduce carbon emissions by changing land use patterns: one is the direct land-use practices to reduce carbon emissions; the other is the indirect land-use practices. (1) Direct land use measures to reduce carbon emissions include reducing surface hardening, construction of green buildings, low-carbon infrastructure, land intensive use. Moreover, emphasis on the ecological benefits of land use, for instance, protection of forests, grasslands and wetlands can contribute to the situation. (2) indirect land-use practices to reduce carbon emissions including land policy, land intensive use, tax regulation and carbon trading market. First, land policy in low-carbon economy, while the process of land supply mainly refers to the prices, modes of supply, structure and quantity. Second, the control of land use from extensive denotative development to intensive development, improve the efficiency of land use. Third, the tax regulation. Levy heavy taxes on extensive denotative development and levy less tax on intensive land use. Fourth, the carbon trading market, while the buyer can obtain emission credits for mitigation of greenhouse emissions in order to meet its low-carbon objectives, namely, trading carbon emission rights.

We suggest that continue to deepen the resource allocation effect of market mechanisms can serve as the possible solution to the situation. One facet of government power, especially in China, is the ability on land market and urban planning. By directing a low-carbon planning, effective space-time allocation of land resources, structural optimization, scale control, function 
enhancement will effectively guide the development pattern, thus promoting the formation of high-tech, low resource consumption, low pollution, and low-carbon development. Specifically,(1)Establish incentive mechanism to revitalize the construction land use, prevent new urban construction's from over-reliance on land revenue which may lead to low-quality of land urbanization; (2) Establish scientific planning and intensive land evaluation regulation, to promote urban land intensive and efficient utilization; (3) Through a unified construction land market in urban and rural areas to increase land use indicator for cities; (4)Charge on real estate to reasonable control urban expansion, and provide sources of sustainable city construction.

Finally, different from previous studies, which state that urbanization and land use greatly lead to carbon emissions (Dhakal, 2009; Zhang\& Lin, 2012), this research suggests that land urbanization can actually contribute to reduction in carbon emissions. Indicate the ongoing industrial restructuring and green developments have come into force. In the formulation and implementation of development planning, to promote green development as the clear theme for institutional innovation and local economic growth. Meanwhile, highlight in green achievements, strengthen a green assessment, weakening GDP evaluation, and increase the proportion of green performance and related indicators for the evaluation of local governments. As for the case of Central China, which has bidirectional largest effects between LUQ and carbon emissions(-0.6253 and -0.2668 ) with highest potential for emission reduction.Possible strategies for the area such as (1) strengthening energy conservation transportation, and other aspects of low-carbon family life: give priority to the development of urban public transportation; (2) to vigorously develop the tertiary industry, increase its share in the national economy, especially in developing low energy consumption, pollution, modern services. In the Eastern region, encourage the development of high-tech industries, giving priority to the development of low energy consumption, namely, information industries which would have a significant effect on the national development. Limiting the development of iron and steel, nonferrous metals, cement and other high energy-consuming industries, meanwhile raising industry access standards. The key of green development of Western China lies in the transformation of the current over-reliance on capital-intensive industries, especially mining and raw materials industry. Possible solutions to the situations such as give full play to the role of human capital, cultivating high technology to make industrial development. Meanwhile, manufacturing should be transferred to small and medium sized cities, while larger cities in the area should give more emphasis to the commercial and financial services. It is entirely possible for the provinces in the area to control industrial pollution emissions from the very beginning.

Generally speaking, our study contributes to literature in the related area since we investigate land urbanization quality from its moderation with economic, social and ecological development. Meanwhile, we attempt to test the possible causal links between the carbon emissions and LUQ considering regional difference. Nevertheless, further studies are needed especially on the function mechanism between urban development and sustainable land use. Besides, this study has not covered the specific land conversion and its possible environmental effects, and we would prefer to extend our research area to our countries in future studies. The research itself can be enhanced if specific land type conversion is included. Currently, the systematic study of the land itself in the number of low-carbon planning structure and spatial layout as well as an assessment of the implementation of land control policies is still very lacking. Future researches should combined with urban social and economic development plans and land-use planning, starting from the 
perspective of population, industry, urban spatial morphology, urban land use and other aspects, by constructing scenarios to simulate the effect of various carbon management policies, and ultimately achieve the goal of low-carbon optimization.

\section{Acknowledgments}

Authors gratefully acknowledge the financial support by National Science Foundation of China (Grants: 71203157 and 71203156).

\section{References}

Al-Mulali, U., \& Sab, C. N. B. C., 2012. The impact of energy consumption and CO 2 emission on the economic growth and financial development in the Sub Saharan African countries. Energy, 39(1), 180-186.

Asumadu-Sarkodie, S., \& Owusu, P. A. 2016. Carbon dioxide emissions, GDP, energy use, and population growth: a multivariate and causality analysis for Ghana, 1971-2013. Environmental Science and Pollution Research, $1-13$.

Barton, H. 2009. Land use planning and health and well-being 구. Land Use Policy, 26(12), S115-S123.

Brown, P. C., \& Matsuo-Chun, J. 2016. Cultivating commons: joint ownership of arable land in early modern Japan. Oceanic Linguistics, 55(1).

Chau, K. W., \& Wu, C. L. 2010. A hybrid model coupled with singular spectrum analysis for daily rainfall prediction. Journal of Hydroinformatics, 12(4), 458-473.

Chen, M., Lu, D., \& Zha, L., 2010. The comprehensive evaluation of China's urbanization and effects on resources and environment. Journal of Geographical Sciences, 20(1), 17-30.

Choy, L.H.T., Lai, Y., \& Lok, W. 2013. Economic performance of industrial development on collective land in the urbanization process in China: empirical evidence from Shenzhen. Habitat International, 40, 184-193.

Chuai, X., Huang, X., Wang, W., Zhao, R., Zhang, M., \& Wu, C. 2015. Land use, total carbon emissions change and low carbon land management in Coastal Jiangsu, China. Journal of Cleaner Production, 103, 77-86.

Chuai, X.W., Huang, X.J., Wang, W.J., Wen, J.Q., 2012. Spatial econometric analysis of carbon emissions from energy consumption in China. Journal of Geographical Sciences 22(4), 630-642.

Davidson, J., \& Wibberley, G. 2016. Planning and the Rural Environment: Urban and Regional Planning Series. Elsevier.

De Rosa, M., Knudsen, M. T., \& Hermansen, J. E. 2016. A comparison of Land Use Change models: challenges and future developments. Journal of Cleaner Production, 113, 183-193.

Destek, M. A., Balli, E., \& Manga, M. 2016. The Relationship between $\mathrm{CO}_{2}$ Emission, Energy Consumption, Urbanization and Trade Openness for Selected CEECs. Research in World Economy, 7(1), p52.

Du, J., Thill, J. C., \& Peiser, R. B. 2016. Land pricing and its impact on land use efficiency in post-land-reform China: A case study of Beijing. Cities, 50, 68-74.

Edmonds, J.A., Clarke, J., Dooley, J., Kim, S.H., Izaurralde, R., Rosenberg, N., Stokes, G., 2003.The potential role of biotechnology in addressing the long-term problem of climate change in the context of global energy and ecosystems. In: Gale, J., Kaya, Y. (Eds.), Greenhouse Gas Control Technologies. Pergamon, Amsterdam, pp. $1427-1432$. 
Edwards, M. M., \& Haines, A. 2007. Evaluating smart growth implications for small communities. Journal of Planning Education and Research, 27(1), 49-64.

Fang, C., Wang, S., \& Li, G., 2015. Changing urban forms and carbon dioxide emissions in China: A case study of 30 provincial capital cities. Applied Energy, 158, 519-531.

Farhani, S., Mrizak, S., Chaibi, A., \& Rault, C., 2014. The environmental Kuznets curve and sustainability: A panel data analysis. Energy Policy, 71, 189-198.

Feng, K., Zheng, J. E., Wei, S. C., Zheng, W. J., \& Liu, Y. 2007. Spatial difference of urban land intensive use based on the GIS and PSR model -A case study of Zhejiang province. Economic Geography, 5, 023.(in Chinese)

Fohrer, N., Haverkamp, S., \& Frede, H. G. 2005. Assessment of the effects of land use patterns on hydrologic landscape functions: development of sustainable land use concepts for low mountain range areas. Hydrological processes, 19(3), 659-672.

Fröhlich, H. L., Schreinemachers, P., Stahr, K., \& Clemens, G. (Eds.). 2013. Sustainable Land Use and Rural Development in Southeast Asia: Innovations and Policies for Mountainous Areas. Springer Science \& Business Media.

Fu, P., \& Weng, Q. 2016. A time series analysis of urbanization induced land use and land cover change and its impact on land surface temperature with Landsat imagery. Remote Sensing of Environment, 175, 205-214.

Granger, C. W. 1969. Investigating causal relations by econometric models and cross-spectral methods. Econometrica: Journal of the Econometric Society, 424-438.

Hansen, B. E., \& Phillips, P. C. 1990. Estimation and inference in models of cointegration: A simulation study. Advances in Econometrics, 8(1989), 225-248.

He, C., Chen, T., Mao, X., \& Zhou, Y. 2016. Economic transition, urbanization and population redistribution in china. Habitat International, 51, 39-47.

He, C., Zhou, Y., \& Huang, Z. 2015. Fiscal decentralization, political centralization, and land urbanization in China. Urban Geography, 1-22.

Hori, S., Kondo, K., Nogata, D., \& Han, B., 2013. The determinants of household energy-saving behavior: survey and comparison in five major asian cities. Energy Policy, 52(3), 354-362

Hubacek, K., \& Giljum, S. 2003. Applying physical input-output analysis to estimate land appropriation (ecological footprints) of international trade activities. Ecological economics, 44(1), 137-151.

Intergovernmental Panel on Climate Change. 2015. Climate change 2014: mitigation of climate change (Vol. 3). Cambridge University Press.

Jin, J., \& Wang, Q. 2016. Assessing ecological vulnerability in western China based on Time-Integrated NDVI data. Journal of Arid Land, 8(4), 533-545.

Johansen, S., 1988., Statistical analysis of cointegration vectors. Journal of economic dynamics and control, 12(2), 231-254.

Kao, C., 1999. Spurious regression and residual-based tests for cointegration in panel data. Journal of econometrics, 90(1), 1-44.

Khan, H. N., Khan, M. A., Razli, R. B., Sahfie, A. B., Shehzada, G., \& Krebs, K. L., et al. 2015. Health care expenditure and economic growth in saarc countries (1995-2012): a panel causality analysis. Applied Research in Quality of Life, January(2015), 1-23.

Kumar Mandal, S. \& S. Madheswaran., 2010. Causality between energy consumption and output growth in the Indian cement industry: An application of the panel vector error correction model (VECM). Energy Policy 38 
(11): 6560-6565.

Li, X. G., \& Zhang, H. M. 2014. The Empirical Research of the Relationship between Economic Growth and Energy Consumption in Hebei Province. In Advanced Materials Research (Vol. 962, pp. 2191-2194). Trans Tech Publications.

Lin, X., Wang, Y., Wang, S., \& Wang, D. 2015. Spatial differences and driving forces of land urbanization in china. Journal of Geographical Sciences, 25(5), 545-558.

Liu Y, Xiao H, Lv Y, Zhang N., 2015. The effect of New-type Urbanization on Energy Consumption in China: A Spatial Econometric Analysis. Journal of Cleaner Production

Liu, S., Maimaitiaili, B., Joergensen, R. G., \& Feng, G. 2016. Response of soil microorganisms after converting a saline desert to arable land in central Asia. Applied Soil Ecology, 98, 1-7.

Liu, Y., Song, Y., \& Song, X., 2014. An empirical study on the relationship between urban compactness and CO 2 efficiency in China. Habitat International, 41, 92-98.

Lu ,D.D., Yao S.M., Li G.P et al., 2007. Comprehensive analysis of the urbanization process based on China's conditions. Economic Geography, 27(6): 883-887. (in Chinese)

Mahadevan, R. \& J. Asafu-Adjaye., 2007. Energy consumption, economic growth and prices: A reassessment using panel VECM for developed and developing countries. Energy Policy 35(4): 2481-2490.

Mandal, S. K., \& Madheswaran, S., 2010. Causality between energy consumption and output growth in the Indian cement industry: An application of the panel vector error correction model (VECM). Energy Policy, 38(11), 6560-6565.

Meng, Q., Xu, L., Zhang, Y., Qian, J., Cai, M., Xin, Y., ... \& Barber, S. L. (2012). Trends in access to health services and financial protection in China between 2003 and 2011: a cross-sectional study. The Lancet, 379(9818), 805-814.

Mu, B., Mayer, A. L., He, R., \& Tian, G. 2016. Land use dynamics and policy implications in Central China: A case study of Zhengzhou. Cities, 58, 39-49.

Ogundari, K. (2016). Maize supply response to price and nonprice determinants in Nigeria: bounds testing approach. International Transactions in Operational Research.

Olivier, J. G. J., Janssens-Maenhout, G., \& Peters, J. A. H. W. (2012). Trends in global co2 emissions. Emissions Database for Global Atmospheric Research Edgar.

Örsal, D. D. K., 2007. Comparison of panel cointegration tests (No. 2007, 029). SFB 649 discussion paper.

Ou, J., Liu, X., Li, X., \& Chen, Y., 2013. Quantifying the relationship between urban forms and carbon emissions using panel data analysis. Landscape ecology, 28(10), 1889-1907.

Pedroni, P., 1999. Critical values for cointegration tests in heterogeneous panels with multiple regressors. Oxford Bulletin of Economics and statistics,61(S1), 653-670.

Pedroni, P., 2004. Panel cointegration: asymptotic and finite sample properties of pooled time series tests with an application to the PPP hypothesis. Econometric theory, 20(03), 597-625.

Peters, G. P., Marland, G., Le Quéré, C., Boden, T., Canadell, J. G., \& Raupach, M. R., 2012. Rapid growth in CO2 emissions after the 2008-2009 global financial crisis. Nature Climate Change, 2(1), 2-4.

Reed, J., Van Vianen, J., Deakin, E. L., Barlow, J., \& Sunderland, T. 2016. Integrated landscape approaches to managing social and environmental issues in the tropics: learning from the past to guide the future. Global change biology, 22(7), 2540-2554.

Rizvi, S. Z. A., \& Nishat, M. 2009. The impact of foreign direct investment on employment opportunities: panel data analysis: empirical evidence from pakistan, india and china. Pakistan Development Review, 48(4), 841- 
851.

Romano, B., \& Zullo, F. 2014. Land urbanization in central italy: 50 years of evolution. Journal of Land Use Science, $9(2), 143-164$.

Rostow, W. W. (1959). The stages of economic growth. The Economic History Review, 12(1), 1-16.

Searchinger, T., Heimlich, R., Houghton, R. A., Dong, F., Elobeid, A., Fabiosa, J., ... \& Yu, T. H., 2008. Use of US croplands for biofuels increases greenhouse gases through emissions from land-use change. Science, 319(5867), 1238-1240.

Tao, Y., Li, F., Wang, R., \& Zhao, D., 2015. Effects of land use and cover change on terrestrial carbon stocks in urbanized areas: a study from changzhou, china. Journal of Cleaner Production, 103, 651-657.

Tugcu C T., 2014. Tourism and economic growth nexus revisited: A panel causality analysis for the case of the Mediterranean Region. Tourism Management, 42, 207-212.

Wang, M., Brunekreef, B., Gehring, U., Szpiro, A., Hoek, G., \& Beelen, R. 2016. A New Technique for Evaluating Land-use Regression Models and Their Impact on Health Effect Estimates. Epidemiology, 27(1), 51-56.

Wang, S., Fang, C., Wang, Y., Huang, Y., \& Ma, H., 2015. Quantifying the relationship between urban development intensity and carbon dioxide emissions using a panel data analysis. Ecological Indicators, 49, 121-131.

Wang, W. C., Xu, D. M., Chau, K. W., \& Lei, G. J. 2014. Assessment of river water quality based on theory of variable fuzzy sets and fuzzy binary comparison method. Water resources management, 28(12), 4183-4200.

Wang, X. (2013). Spatio-temporal changes in agrochemical inputs and the risk assessment before and after the grain-for-green policy in china. Environmental Monitoring \& Assessment, 185(2), 1927-1937.

Wei, X., Wei, C., Cao, X., \& Li, B. (2016). The general land-use planning in China: an uncertainty perspective. Environment and Planning B: Planning and Design, 43(2), 361-380.

Wise, M., Calvin, K., Thomson, A., Clarke, L., Bond-Lamberty, B., Sands, R., ... \& Edmonds, J., 2009. The implications of limiting $\mathrm{CO} 2$ concentrations for agriculture, land-use change emissions, and bioenergy. Pacific Northwest National Laboratory Technical Report PNNL, 18341.

Wise, M., Hodson, E. L., Mignone, B. K., Clarke, L., Waldhoff, S., \& Luckow, P., 2015. An approach to computing marginal land use change carbon intensities for bioenergy in policy applications. Economic Modelling, 47, 307-318.

Xin, Z., \& Zhang, Y. 2008. Low carbon economy and low carbon city. Urban Studies, 4, 98-102.

Xu, C., Wang, S., Zhou, Y., Wang, L., \& Liu, W. 2016. A Comprehensive Quantitative Evaluation of New Sustainable Urbanization Level in 20 Chinese Urban Agglomerations. Sustainability, 8(2), 91.

Xu, G., Huang, X., Zhong, T., Chen, Y., Wu, C., \& Jin, Y. 2015. Assessment on the effect of city arable land protection under the implementation of china's national general land use plan (2006-2020). Habitat International, 49, 466-473.

Yao, X., Wang, Z., \& Zhang, H. 2016. Dynamic Changes of the Ecological Footprint and Its Component Analysis Response to Land Use in Wuhan, China. Sustainability, 8(4), 329.

Zhang. J., 2015. Carbon emission, energy consumption and intermediate goods trade: a regional study of east asia. Energy Policy, 86, 118-122.

Zhao, M. Y., Cheng, C. T., Chau, K. W., \& Li, G. 2006. Multiple criteria data envelopment analysis for full ranking units associated to environment impact assessment. International Journal of Environment and 
Pollution, 28(3-4), 448-464.

Zhao, R., Chuai, X., Huang, X., Lai, L., \& Peng, J. 2014. Carbon Emission and Carbon Footprint of Different Industrial Spaces in Different Regions of China. Assessment of Carbon Footprint in Different Industrial Sectors, Volume 1. Springer Singapore.

Zhou, D., Xu, J., Wang, L., \& Lin, Z. 2015. Assessing urbanization quality using structure and function analyses: a case study of the urban agglomeration around hangzhou bay (uahb), china. Habitat International, 49, 165-176.

\section{Appendix}

Table 3 Evaluation results of land urbanization quality

\begin{tabular}{|c|c|c|c|c|c|c|c|c|c|c|}
\hline Province & 2004 & 2005 & 2006 & 2007 & 2008 & 2009 & 2010 & 2011 & 2012 & 2013 \\
\hline Beijing & 48.95 & 45.26 & 46.59 & 53.62 & 46.26 & 48.66 & 51.60 & 43.97 & 45.42 & 49.46 \\
\hline Tianjin & 47.76 & 46.35 & 41.26 & 20.56 & 18.00 & 42.62 & 46.32 & 37.05 & 43.96 & 50.21 \\
\hline Hebei & 58.74 & 51.79 & 47.02 & 56.73 & 55.18 & 55.58 & 54.45 & 44.46 & 47.21 & 53.88 \\
\hline Shanxi & 60.94 & 58.20 & 44.43 & 49.34 & 54.11 & 50.92 & 48.97 & 36.90 & 39.40 & 45.80 \\
\hline Inner Mongolia & 45.29 & 42.02 & 44.12 & 44.01 & 50.43 & 47.99 & 42.59 & 36.75 & 37.63 & 42.07 \\
\hline Liaoning & 44.13 & 42.25 & 39.78 & 45.42 & 48.34 & 44.91 & 41.00 & 37.28 & 41.33 & 43.58 \\
\hline Jilin & 41.03 & 37.60 & 27.83 & 38.92 & 35.77 & 36.94 & 34.73 & 24.98 & 31.63 & 32.87 \\
\hline Heilongjiang & 40.17 & 29.78 & 27.28 & 31.30 & 40.00 & 36.62 & 33.30 & 27.78 & 29.17 & 35.69 \\
\hline Shanghai & 58.88 & 61.49 & 53.76 & 65.37 & 35.91 & 37.24 & 61.53 & 61.35 & 55.12 & 65.13 \\
\hline Jiangsu & 55.11 & 49.83 & 49.57 & 56.32 & 49.38 & 49.72 & 46.45 & 34.23 & 37.94 & 45.26 \\
\hline Zhejiang & 62.99 & 49.93 & 50.39 & 53.91 & 56.97 & 57.25 & 50.05 & 34.37 & 41.34 & 49.28 \\
\hline Anhui & 36.82 & 28.34 & 40.39 & 42.07 & 40.35 & 44.72 & 40.01 & 29.55 & 33.56 & 42.70 \\
\hline Fujian & 58.93 & 51.68 & 42.94 & 60.11 & 54.49 & 55.08 & 46.55 & 36.38 & 41.74 & 53.68 \\
\hline Jiangxi & 49.26 & 47.54 & 36.87 & 44.70 & 50.60 & 52.29 & 49.98 & 36.51 & 42.75 & 48.17 \\
\hline Shandong & 55.18 & 41.21 & 43.96 & 46.05 & 44.55 & 45.42 & 38.26 & 29.79 & 34.43 & 37.99 \\
\hline Henan & 48.72 & 43.87 & 40.51 & 46.87 & 48.35 & 46.68 & 42.85 & 34.20 & 39.97 & 48.75 \\
\hline Hubei & 43.88 & 46.11 & 39.90 & 46.78 & 30.88 & 40.63 & 38.23 & 30.75 & 35.97 & 42.76 \\
\hline Hunan & 46.82 & 42.54 & 38.78 & 42.60 & 43.74 & 45.71 & 44.37 & 33.36 & 35.24 & 47.60 \\
\hline Guangdong & 35.15 & 39.47 & 34.27 & 32.33 & 43.36 & 38.95 & 40.52 & 27.25 & 32.65 & 41.56 \\
\hline Guangxi & 41.71 & 37.00 & 40.18 & 38.48 & 40.54 & 42.61 & 37.86 & 28.01 & 36.30 & 41.43 \\
\hline Hainan & 47.69 & 34.97 & 35.21 & 44.59 & 48.68 & 42.52 & 47.90 & 34.98 & 42.68 & 44.59 \\
\hline Chongqing & 52.37 & 38.82 & 40.23 & 48.79 & 48.01 & 47.69 & 42.12 & 25.43 & 42.54 & 45.79 \\
\hline Sichuan & 42.69 & 39.41 & 48.98 & 50.08 & 46.69 & 48.25 & 46.45 & 31.56 & 36.68 & 41.59 \\
\hline Guizhou & 54.53 & 44.07 & 33.67 & 48.19 & 44.11 & 38.66 & 43.33 & 33.15 & 36.80 & 40.12 \\
\hline Yunnan & 49.56 & 46.86 & 33.38 & 40.97 & 42.32 & 44.11 & 33.48 & 35.25 & 38.93 & 44.23 \\
\hline Shannxi & 57.90 & 60.14 & 44.09 & 61.27 & 64.02 & 61.30 & 60.68 & 46.12 & 51.88 & 55.76 \\
\hline Gansu & 41.16 & 43.68 & 29.15 & 31.22 & 32.56 & 33.46 & 30.40 & 26.15 & 31.55 & 37.03 \\
\hline Qinghai & 42.99 & 41.02 & 32.57 & 47.33 & 49.76 & 55.58 & 54.76 & 58.65 & 64.36 & 40.51 \\
\hline Ningxia & 44.64 & 39.12 & 31.96 & 36.37 & 36.45 & 35.52 & 31.63 & 25.06 & 31.75 & 37.68 \\
\hline Xinjiang & 46.78 & 44.79 & 24.68 & 41.58 & 31.87 & 26.68 & 34.20 & 25.09 & 32.32 & 34.58 \\
\hline
\end{tabular}

